\title{
ТРАНСФОРМАЦІЯ ЗМІСТУ НАВЧАЛЬНИХ ДИСЦИПЛІН ЯК ОДНА З НЕОБХІДНИХ УМОВ ПІДГОТОВКИ КОМПЕТЕНТНОГО ФАХІВЦЯ
}

\begin{abstract}
Панішева О. В. Трансформація змісту навчальних дисииплін як одна з необхідних умов підготовки компетентного фахівия.

У статті розглянуто иляхи трансформації змісту дисиипліни «Основи алгоритмізаиіі та математична логіка» задля формування професійних компетентностей майбутніх інженерів-програмистів та вчителів інформатики.

Ключові слова: компетентності, зміст навчання, професійна спрямованість, підготовка майбутнього вчителя, математична логіка.

Панишева О. В. Трансформащия содержания учебных дисииплин как одно из необходимых условий подготовки компетентного специалиста.

В статье рассмотрены пути трансформации содержания дисииплины «Основы алгоритмизации и математическая логика» с иелью формирования профессиональных компетентностей будущих инженеров-программистов и учителей информатики.

Ключевые слова: компетентности, содержание обучения, профессиональная направленность, подготовка будущего учителя, математическая логика.

Panisheva $O$. The transformation of the content of academic disciplines as a prerequisite for the preparation of a competent professional.

In article ways of transformation of the contents of discipline "Bases of algorithmization and the mathematical logic» for the purpose of formation professional competences the future engineersprogrammers and teachers of computer science are considered.

Key words: competence, contents of training, professional orientation, training of teachers, the mathematical logic.
\end{abstract}

Актуальність дослідження. У сучасному суспільстві професійна компетентність стає однією з умов успішності людини в житті. Поняття «компетентність» пояснюється як набута характеристика особистості, яка, грунтуючись на певних ціннісних переконаннях, охоплює відповідні знання, уміння і навички та дозволяє застосовувати останні в самостійній практичній діяльності для реалізації власного життєвого потенціалу [4, с. 54]. Дослідники виокремлюють різні групи компетентностей, що мають бути сформовані у студентів. Зокрема, ключові, або базові, професійні та предметні компетентності [2, с. 256]. Питанням формування основних компетентностей присвячено чимало наукових досліджень, серед яких доробки Н. Бібик, О. Пометун, І. Родигіної, О. Шавальової та інших.

Аналіз останніх досліджень і публікацій. Сформувати у студентів базові компетентності у тій галузі, яку вони обрали для майбутньої професійної діяльності, допоможе трансформація змісту навчальних дисциплін залежно від напряму підготовки майбутнього спеціаліста. Ця трансформація відбувається 3 урахуванням одного 3 основних принципів навчання - принципу професійної спрямованості. Різні аспекти професійної спрямованості навчання вивчено такими дослідниками, як Ю. Бабанський, 
А. Колмогоров, В. Монахов та інші. Проблема професійно зорієнтованої математичної підготовки розглянута у роботах 3. Слєпкань, Ю. Колягіна, Г. Іларіонової та інших.

Кожна дисципліна навчального плану в межах своєї предметної специфіки має резерви для розв'язання цього важливого для суспільства завдання - формування базових компетентностей майбутніх фахівців. Найчастіше через призму формування базових професійних компетентностей розглядаються спеціальні дисципліни. Можливості інших навчальних дисциплін, зокрема, математичних, вивчено недостатньо. Ми розглянемо окремі резерви дисципліни «Основи алгоритмізації та математична логіка» 3 навчального плану студентів спеціальності «Інформатика».

Мета статті - ознайомити 3 власним досвідом трансформації змісту дисципліни «Основи алгоритмізації та математична логіка», реалізації принципу професійної спрямованості у викладанні цієї дисципліни задля формування базових та професійних компетентностей студентів спеціальності «Інформатика».

Виклад основного матеріалу. Змалюємо, як, не виходячи за межі навчального плану, наповнити цю дисципліну професійно спрямованим змістом. Можливості для цього є як на лекціях, так і на практичних заняттях.

У робочій програмі цієї дисципліни $є$ такі традиційні розділи, як «Алгебра логіки», «Математична ситуація, що приводить до виникнення поняття алгоритму», «Скінчені автомати», «Мінімізація скінчених автоматів» тощо. Звичайно, можна обмежитися теоретичним розглядом цих питань та розв'язанням типових вправ. Але, на наш погляд, доцільно додати кілька вправ та завдань, виконання яких підвищить інтерес до предмета, дозволить установити міжпредметні зв'язки, продемонструє важливість вивчення математичної логіки для подальшого професійного розвитку студента, зробить матеріал, що вивчається, особистісно значущим та привабливим 3 позиції майбутньої професійної діяльності. Наведемо кілька прикладів таких завдань.

Перші вправи з математичної логіки представлено як завдання, у яких потрібно вибрати серед запропонованих речень висловлення та з'ясувати, чи $\epsilon$ вони істинними. Серед цих завдань доцільно подати такі, розв'язання яких, окрім основної дидактичної задачі - формування уміння вибирати висловлення серед інших речень та з'ясовувати їхні логічні значення, - має пізнавальну цінність, дозволяє надавати студентам корисні відомості з інших дисциплін, розширювати їхній загальний світогляд. Різнобічність, обізнаність з багатьох питань загальної культури, широкий світогляд невід'ємний складник формування базових компетентностей майбутнього вчителя інформатики. Тому вправи для першого практичного заняття складаємо так, щоб вони стосувалися різних галузей знань. Наприклад, пропонуємо з'ясувати істинність таких висловлень: «Маяковський написав «Війну і мир»»); «Найвища гора у світі - Сагарматха», «Свинець не тоне у воді», «Земля - третя від Сонця планета» тощо. Якщо студент утруднюється дати відразу відповідь, він може скористатися енциклопедіями, довідниками 
або знайти відповідь в одній 3 пошукових систем. Потім додаються висловлення на зразок: «На Марсі було життя», «Існує нескінченна кількість простих чисел вигляду $2^{n}-1 »$, «1 травня першого року нової ери у нашій місцевості йшов дощ». Знайти відповідь, тобто вказати, чи істинні ці висловлення, неможливо в жодній з паперових чи електронних енциклопедій. Але ці речення, навіть якщо ми нині не можемо з'ясувати їхнє логічне значення, також є висловленнями. Це гіпотези. I хоч навряд чи коли-небудь буде можливість визначити істинність останнього речення, але немає сумнівів, що воно або хибне, або істинне. Наводимо й інші речення: «За дурною головою і ногам немає спокою», «За допомогою філософського каменю можна перетворити свинець на золото», які неможливо розподілити на істині чи хибні.

Потім розглядаємо пари парадоксальних речень. Наприклад, така пара: «друге речення - хибне»; «перше речення - істинне». Із якого речення не розпочали б визначати їхню істинність, отримаємо суперечність.

Такі приклади демонструють, що звичайна мова допускає граматично правильні конструкції, які мають вигляд тверджень, та про які неможливо сказати, чи істині вони, чи ні. Такі «примари» зустрічаються й у математичних доведеннях. Прикладом може стати «парадокс голяра», що виник у теорії множин на межі XIX-XX ст. Щоб запобігти появі таких парадоксів, необхідна побудова формальних мов, у яких немає вольностей мов природних [3, с. 582]. До такого висновку студенти доходять майже самостійно, а спрямовує їх до нього уміло дібрана система завдань. Отже, наприкінці заняття отримуємо сформовану мотивацію необхідності вивчення мови формальної логіки, що є предметом розгляду на наступних заняттях.

Традиційно при ознайомленні студентів 3 основними логічними операціями наводяться відповідні визначення та таблиці істинності основних логічних операцій, закони виконання дій над висловленнями. Тема легко засвоюється студентами, кількох прикладів і нескладних вправ виявляється достатньо для формування відповідних умінь і навичок. Та в багатьох підручниках i збірниках задач приклади i завдання носять загальний характер. Цими завданнями зазвичай підкреслюється, що в математичній логіці не важливий зміст висловлення, а важливе тільки його логічне значення. Так, найчастіше пропонується 3'ясувати істинність висловлень на кшталт «Якщо Київ - столиця України, то 2+3 = 7». Але такі й аналогічні завдання не відображають особливостей застосування логічних операцій у програмуванні. Отже, зміст навчального матеріалу з цієї теми у підручниках i задачниках не дозволяє повноцінно реалізовувати принцип професійної спрямованості, бо в підручниках дуже обмежена кількість прикладів, які б стосувалися професійних інтересів чи професійних обов'язків майбутніх фахівців, або такі приклади повністю відсутні. Тому викладачеві доводиться трансформувати цей зміст, доповнювати його.

Підвищити професійний інтерес до вивчення цієї теми допоможуть відомі методичні прийоми «дивуй!» та «відстрочена відгадка». Після ознайомлення 
3 визначеннями операцій кон'юнкції та диз'юнкції й їхніми таблицями істинності зауважуємо, що ці операції $є$ невід'ємною частиною всіх мов програмування. На клавіатурах комп'ютерів немає символів для позначення кон'юнкції й диз'юнкції, і замість них часто вживають англійські слова AND та OR. Уживання слів замість символів часто призводить до помилок майбутніх програмістів. Щоб попередити ці помилки, розповідаємо притчу.

«Султан повертався додому з перемогою. За традицією, у столиці армію мали зустрічати артилерійським салютом. Але міські гармати мовчали. Султан запросив до себе головного візиря та вимагав пояснень.

- Повелитель, - почав пояснення візир, - на те було 12 причин. По-перше, у нас скінчився порох.

- Досить, - сказав султан і наказав відрубати візиру голову» [3, с. 584].

Студенти поки що не розуміють, до чого ця притча. Викладач пояснює далі, що у математичній логіці немає різниці, написати $\mathrm{A} \wedge \mathrm{B}$ чи $\mathrm{B} \wedge \mathrm{A}$. Тут, як і в арифметиці, справджується комутативний закон, і від зміни місць множників добуток не змінюється. У програмуванні ж заміна «A AND B» на «B AND A» може суттєво змінити поведінку програми. Наприклад, ми отримаємо повідомлення про помилку «ділення на нуль», якщо перед виконанням оператора «IF $\mathrm{Y} / \mathrm{X}>\mathrm{Z}$ AND $\mathrm{X}>0$ THEN...» значення змінної $\mathrm{X}$ дорівнювало нулю. У той же час, аварійної зупинки не відбудеться, якщо написати «IF $\mathrm{X}>0$ AND $\mathrm{Y} / \mathrm{X}>\mathrm{ZTHEN} . . . »$. Річ у тім, що відповідно до семантики деяких мов програмування комп'ютер може діяти як султан у притчі: спочатку обчислює значення першого члена кон'юнкції. Якщо воно хибне (дорівнює 0), то другий член кон'юнкції просто ігнорується. Аналогічно, ігнорується i другий член диз'юнкції, якщо перший ii член приймає значення «істина».

Наповнювати навчання логіки професійно значущим змістом можна не тільки через такі повчальні приклади, а й завдяки практичному моделюванню окремих теоретичних ситуацій. Так, ознайомивши студентів 3 математичною ситуацією, яка зумовлює виникнення поняття алгоритму, доцільно докладно розглянути абстрактні теоретичні машини - машини Тюрінга та Поста - та принципи їх дії. Можна навіть змоделювати машину Поста і на конкретних прикладах продемонструвати ii роботу. Для цього пропонуємо викласти на партах у рядок паперові клітинки і на окремі 3 них помістити картонні кубики, розміри яких збігаються з розмірами клітинок. Під цим рядком розміщуємо звичайну кулькову ручку, яка грає роль кульки. Потім надаємо перелік дозволених дій та їхній символічний запис. Це шість найпростіших операцій: зсув кульки праворуч, ліворуч, поставити кубик у клітинку над кулькою, зняти кубик, перевірка, чи секція над кулькою порожня і операція «стій» [1, с.122]. Після цього студентам пропонується виконати найпростішу програму. Причому результат виконання цієї програми залежно від того, як були розміщені кубики, у кожного студента різний. Після цього клітинки, заповнені кубиками, замінюємо 1, а порожні 0, і пропонуємо вже завдання 3 перетворення двійкової інформації за іншою, 
більш складною програмою. Потім пропонуємо студентам скласти програму для виконання такого ж завдання (наприклад, заповнити порожні клітинки кубиками) за допомогою однієї з сучасних мов програмування.

Порівнюючи програму для машини Поста із записом програм сучасними мовами програмування, способами записів алгоритмів, студент може побачити ту основу, яка лишилася незмінною. Майбутній фахівець починає розуміти, що машина Поста не що інше, як «бабуся» сучасних ЕОМ, така собі логічна рахівниця, за допомогою якої ідею програмування можна «пощупати власними руками», побачити власними очима усю «кухню» програмування. Простота машини Поста ніяк не обмежує ії можливостей «у принципі», та програми для перетворення інформації $\epsilon$ дуже довгими, громіздкими. Виникає повага до перших програмістів, розуміння необхідності вдосконалення мов для спілкування з машинами.

Не менше можливостей для реалізації принципу професійної спрямованості надає вивчення теми «Скінчені автомати». Справжній компетентний фахівець має бути обізнаний не тільки із сучасним станом речей, а й 3 історією розвитку своєї галузі. Задля цього під час вивчення скінчених автоматів пропонуємо студентам ознайомитися 3 історією розвитку автоматики, підготувати презентацію та сконструювати власноруч модель одного з автоматів, пояснити, що в ньому становлять множини вхідних та вихідних символів, внутрішніх станів, спробувати задати роботу цього автомату теоретично. Ця робота становить творчий проект і здійснюється у групах. Тут студенти можуть розповідати про найпростіші автомати - перші пастки для звірів, торгові автомати часів Герона та Архімеда тощо. Отже, ми розвиваємо інженерне та технічне мислення майбутніх програмістів, що $\epsilon$ необхідною складовою професійної компетентності.

Цікавим та повчальним під час розгляду проблеми мінімізації скінчених автоматів є вивчення літератури другої половини минулого століття, у якій прогнозується розвиток автоматики XXI ст. Аналіз причин, через які не внадалося реалізувати творчі задуми фахівців, якнайпереконливіше доводить необхідність розв'язання проблеми мінімізації автоматів, мотивує студентів до вивчення теоретичних основ цього процесу.

Висновки та перспективи подальших розвідок. Отже, трансформація змісту дисципліни «Математична логіка» відбувається через його доповнення професійно значущими знаннями, демонстрацію міжпрежметних зв'язків, виконання спеціально дібраних вправ. Це не знижує якості знань, а навпаки, надає їм професійної спрямованості. Основні теми робочої програми при цьому залишаються незмінними.

Виявлення потенціалу трансформації змісту інших математичних дисциплін з позиції формування базових компетентностей майбутнього вчителя інформатики - один із напрямків подальших наукових розвідок. Добірка практичного матеріалу, який дозволяє здійснювати принцип професійної спрямованості у викладанні математичних дисциплін майбутнім учителям інформатики, укладання системи дидактичних завдань професійно 
спрямованого змісту, пошук сучасних методів, прийомів та форм навчання, що сприяють становленню ключових та професійних компетентностей майбутніх фахівців, створення спеціальних навчальних посібників для студентів певної спеціальності є перспективними практичними завданнями викладачів вищої школи.

Отже, якщо вивчення математичної логіки ведеться з урахуванням принципу професійної спрямованості, то студенти бачать роль та значення дисципліни у своєму професійному становленні, зростає вмотивованість вивчення як окремих тем, так і всієї дисципліни, зацікавленість предметом, що сприяє досягненню кінцевої мети - становленню компетентного фахівця.

\section{Література}

1. Касаткін В. Крок за кроком за ЕОМ / Валентин Касаткін. - К. : Веселка, 1979. - 160 с.

2. Тіхонцова Н. I. Математична освіта студентів у світлі впровадження компетентністного підходу / Н. I. Тіхонцова // Матеріали всеукр. наук.-практ. конф. «Методологічні та методичні основи активізації навчально-пізнавальної діяльності студентів у процесі вивчення математичних дисциплін» ; 23-24 листопада 2009 р. - Ялта : РВВ КГУ, 2009. - Вип. 3. - С. 252-256.

3. Энциклопедия для детей. Т.11. Математика. - М. : Аванта +, 2004. - 688 с.

4. Якухно I.I. Компетентнісний підхід - шлях до Свропейської якості освіти / I.I. Якухно // Матеріали Міжнар. наук.-практ. конф. «Компетентністно орієнтована освіта: досвід, проблеми, перспективи» ; 5-6 листопада 2008 р. - Донецьк: Каштан, 2008. - С.54-59.

Стаття надійшла до редакції 30.04.2012 р.

УДК 373. 21: 172.3

К. О. Романюк, аспірант,

Прикарпатський національний університет ім. В. Стефаника

\section{ФОРМУВАННЯ ГОТОВНОСТІ ПЕДАГОГІВ ДНЗ ДО ВИХОВАННЯ МІЖЕТНІЧНОЇ ТОЛЕРАНТНОСТІ ДІТЕЙ (ЗА РЕЗУЛЬТАТАМИ ЕКСПЕРИМЕНТАЛЬНОГО ДОСЛІДЖЕННЯ)}

\footnotetext{
Романюк К.О. Формування готовності педагогів ДНЗ до виховання міжетнічної толерантності дітей (за результатами експериментального дослідження).

У статті автор визначає проблему формування міжетнічної толерантності як одну з актуальних в сучасній педагогічній науці. На основі опрачювання результатів експериментального дослідження визначено рівень готовності педагога та його роль у прочесі виховання міжетнічної толерантності дітей стариого дошкільного віку, зміст його діяльності в контексті окресленої проблеми, а також виокремлено шляхи підвищення фахового рівня педагогів.

Ключові слова: міжетнічна толерантність, навчально-виховний прочес, базова програма, компетентність.

Романюк К. А. Формирование готовности педагогов детского учебного учреждения $к$ воспитанию толерантности детей (по результатам экспериментального исследования).

В статье автор определяет проблему формирования межэтнической толерантности как одну из актуальных в современной педагогической науке. Анализ результатов экспериментального исследования позволил определить уровень готовности педагога и его роль в процессе воспитания межэтнической толерантности детей старшего дошкольного возраста, содержание его деятельности в контексте данной проблемы, а также пути повымения профессионального уровня педагогов.
} 